\title{
KOMITMEN TERHADAP ORGANISASI DILIHAT DARI KEADILAN KOMPENSASI STUDI KASUS DI SALAH SATU RUMAH SAKIT SWASTA DI KOTA SEMARANG
}

\author{
Ariyani Indriastuti, Th. Susetyarsi \\ Program Studi Manajemen STIE SEMARANG \\ ariyani@stiesemarang.ac.id
}

\begin{abstract}
The Purpose of the research is to determine the effect of fairness compensation on organizational commitment. Fairness of compensation is indicated by salary, incentives, bonuses, benefits, insurance and pension guarantees. This research is a causal associative research using a quantitative approach. The sample of this study was nurses in one hospital at Semarang City. Data collection using questionnaires and interviews, the sampling technique is purposive sampling obtained 81 samples. Data analysis using multiple linear regression. The research indicate that: 1) Salary has no significant effect on organizational commitment, 2). Incentives have a positive and significant effect on organizational commitment. 3). bonuses have a positive and significant impact on organizational commitment. 4). Allowances have a positive and significant effect on organizational commitment. 5). Insurance has no significant effect on organizational commitment. 6). Pension insurance has a positive and significant effect on organizational commitment.
\end{abstract}

\section{Keyword : fairnes compensation, organizationel commitmet}

\begin{abstract}
ABSTRAK
Penelitian ini bertujuan untuk mengetahui pengaruh keadilan kompensasi terhadap komitmen organisasi. Keadilan kompensasi ditunjukan dengan variabel gaji, insentif, bonus, tunjangan, asuransi dan jaminan pensiun. Penelitian ini merupakan penelitian asosiatif kausal dengan menggunakan pendekatan kuantitatif. Sampel penelitian ini adalah perawat di salah satu rumah sakit swasta di Kota Semarang. Pengumpulan data menggunakan kuesioner dan wawancara, teknik pengambilan sampel adalah purposive sampling diperoleh sampel 81 . Analisis data menggunakan regresi linier berganda. Hasil penelitian pada taraf signifikansi 5\% menunjukkan bahwa: 1) Gaji tidak berpengaruh signifikan terhadap komitmen organisasi, 2).insentif berpengaruh positif dan sigifikan terhap komitmen organisasi. 3). bonus berpengaruh positif dan sigifikan terhap komitmen organisasi. 4). Tunjangan berpengaruh positif dan sigifikan terhadap komitmen organisasi. 5). Asuransi tidak berpengaruh sigifikan terhap komitmen organisasi. 6). Jaminan pensiun berpengaruh positif dan sigifikan terhap komitmen organisasi.
\end{abstract}

\section{Kata Kunci : Komitmen organisasi, keadilan kompensasi}

\section{PENDAHULUAN}

Organisasi membutuhkan berbagai sumber daya seperti modal, material, mesin serta sumber daya manusia untuk menjalankan aktifitas bisnisnya. Aspek sumber daya manusia memegang peranan penting dalam sebuah organisasi karena dapat memunculkan perilaku produktif. Disini dapat dilihat peran sumberdaya manusia dalam suatu organisasi merupakan penentu 
yang sangat penting bagi keefektifan dan keberhasilan organisasi dalam mencapai tujuan, yaitu meningkatkan kemakmuran. Pada dasarnya manusia bekerja ingin memperoleh pendapatan untuk memenuhi kebutuhan hidupnya. Agar kebutuhan hidup dapat tercapai maka manusia akan cenderung mencari tempat kerja yang mampu memberikan kompensasi yang dinilai layak. Seorang karyawan mulai menghargai kerja keras dan semakin menunjukan loyalitas terhadap perusahaan dan karena itulah perusahaan memberikan penghargaan terhadap prestasi kerja karyawan yaitu dengan memberikan kompensasi. Salah satu cara manajemen untuk meningkatkan prestasi kerja, memotivasi dan meningkatkan kinerja para karyawan adalah melalui kompensasi.

Kompensasi adalah faktor penting yang mempengaruhi bagaimana dan mengapa karyawan bekerja pada suatu organisasi merujuk pada semua bentuk balas jasa bagi karyawan yang berasal dari penyelesaian pekerjaan mereka. Bukan hanya kompensasi yang dapat menentukan keberhasilan perusahaan dan menjaga tingkat perputaran karyawan, tetapi juga dipengaruhi oleh sumber daya manusia yang berkualitas dan tergantung bagaimana perusahaan mampu memanfaatkan peluang yang ada dan mengatasi ancaman dari luar dengan memanfaatkan sumber daya manusia yang dimiliki, karena itu perusahaan mempunyai kewajiban untuk mengelola sumber daya manusianya dengan baik.

Tujuan pemberian kompensasi adalah meningkatkan kepuasan dan produktivitas kerja karyawan sehingga kayawan memiliki komitmen terhadap organisasi yang tinggi._Komitmen kerja tidak secara otomatis muncul pada karyawan. Ada sejumlah faktor yang mempengaruhi munculnya komitmen kerja ini, baik yang berasal dari dalam atau diri individu maupun berasal dari faktor eksternal/organisasi.

Berapa hasil penelitian menunjukan bahwa kompensasi berpengaruh signifikan terhadap komitmen organisasi (Ervanda Wildam Pratama,2016, Wilujeng Rahayu, 2012). Sedangkan Dewi Puspitasari, (2011) menyatakan bahwa pendapatan financial tidak berpengaruh signifikan terhadap komitmen organisasi.

Salah satu aspek yang penting untuk diperhatikan perusahaan, terkait dengan peran sumber daya manusia adalah intensitas keluar karyawan (turn over intensions) yang memiliki kaitan erat dengan komitmen organisasi. Komitmen karyawan pada perusahaan adalah suatu perasaan atau orientasi emosional karyawan kepada perusahaan atau organisasi yang mencakup komitmen, identifikasi, dan keterlibatan antara anggota dengan organisasinya. Salah satu bentuk rendahnya komitemen organisasi dari karyawannnya adalah keinginan untuk pindah dapat dijadikan gejala awal terjadinya turnover dalam sebuah perusahaan. Di suatu rumah sakit karyawan yang mempunyai turnover paling tinggi adalah perawat. Karena 
hal itulah penelitian ini merupakan studi yang bertujuan untuk mengetahui pengaruh keadilan kompensasi terhadap komitmen organisasi .

\section{MASALAH PENELITIAN}

Keefektifan sistem kompensasi dari rumah sakit perlu dianalisis sejauh mana tujuan pemberian kompensasi telah tercapai dan pengaruhnya dalam menciptakan keinginan pada diri karyawan untuk bertahan di rumah sakit ini dalam wujud komitmen organisasi. Selain itu, perlu diketahui juga apakah keadilan kompensasi yang diberikan oleh rumah sakit telah memotivasi karyawan memberikan komitmen organisasi secara optimal. Pertanyaan penelitian dapat dirumuskan adalah Bagaimana pengaruh keadilan kompensasi terhadap komitmen organisasi.

\section{KAJIAN TEORITIS}

\section{Komitmen Organisasi}

Komitmen organisasi merupakan hubungan yang erat antara karyawan dengan kepentingan organisasi (Robbins, 2008). Komitmen organisasi merupakan sikap kesetiaan karyawan kepada organisasi serta mengungkap perhatian pada keberhasilan dan kesejahteraan organisasi. Karyawan yang memiliki tingkat komitmen organisasi yang tinggi akan memiliki sikap loyalitas dalam melibatkan diri secara efektif demi kemajuan organisasi dan menerima tujuan serta nilai-nilai yang ada di dalam perusahaan.

Beberapa faktor yang mempengaruhi tingkat komitmen organisasi karyawan, antara lain: 1) Kompensasi Karyawan yang merasakan adanya keadilan kompensasi sehubungan dengan beban pekerjaan, mengarahkan pada tingkat komitmen yang dimiliki dalam diri karyawan yang berdampak pada kinerja karyawan. Keadilan kompensasi berpengaruh positif terhadap besarnya tingkatan komitmen organisasi karyawan terhadap intensitas keluar karyawan. Kompensasi yang diberikan perusahaan akan memberikan kepuasan apabila persepsi gaji yang mereka peroleh sesuai dengan harapan. Karyawan yang telah merasakan kepuasan dalam bekerja, cenderung akan bertahan didalam organisasi tersebut

Komitmen organisasi merupakan suatu sikap yang akan menentukan perilaku karyawannya. Perwujudan tingginya komitmen organisasi kepada organisasi adalah rendahnya tingkat perputaran karyawan, rendahnya tingkat kemangkiran, tingginya motivasi kerja dan prestasi kerja (Baron dan Greenberg, 2003). Menurut Luthans (2006) terdapat empat hal yang berkaitan dengan pentingnya komitmen organisasi yaitu menunjukkan keikatan terhadap tujuan dan nilai-nilai organisasi, memiliki keinginan kuat untuk berkontibusi aktif 
memajukan perusahaan, peningkatan identifikasi dan kepercayaan terhadap sasaran organisasi, mengerahkan cukup banyak usaha demi kepentingan organisasi

Komitmen organisasi bukan hanya mencangkup kesetiaan kepada organisasi, tetapi proses yang berjalan dimana karyawan dapat mengekspresikan kepeduliannya kepada organisasi dan prestasi kerja yang tinggi. Komitmen organisasional karyawan yang tinggi menjamin keinginan para karyawan agar dapat bekerja dan memberikan sumbangan terbaik, bangga dan setia pada nilai-nilai serta tujuan organisasi.

Komitmen organisasi dibedakan menjadi tiga jenis yang menurut Allen dan Meyer dalam Luthans (2006) diantaranya adalah komitmen afektif yang merupakan keterikatan emosional karyawan terhadap organisasi, komitmen kelanjutan berdasarkan pada kebutuhan keuangan atau pendapatan yang diterima karyawan, dan komitmen normatif berdasarkan pada perasaan wajib untuk tetap terlibat di dalam perusahaan.

\section{Kompensasi}

Menurut Keith Davis dan Werther WB (1996) tujuan manajemen kompensasi adalah untuk membantu perusahaan dalam mencapai tujuan strategis dan menjamin terjadinya keadilan internal dan eksternal. Keadilan eksternal menjamin bahwa pekerjaan dikompenasasi secara adil dengan membandingkan pekerjaan yang sama di pasar kerja.

Menurut Sikula, (2000), imbalan merupakan segala sesuatu yang dianggap sumber balas jasa atau ekuivalen. Simamora (2004) mengatakan bahwa imbalan adalah apa yang diterima oleh para karyawan sebagai ganti kontribusi karyawan kepada organisasi. Salah satu jenis imbalan adalan imbalan finansial atau sering disebut dengan istilah kompensasi. Kompensasi berhubungan dengan imbalan finansial yang diterima oleh orang-orang melalui hubungan kepegawaian mereka dengan sebuah organisasi

Hani Handoko (1993) menyatakan bahwa kompensasi penting bagi karyawan sebagai individu karena besarnya kompensasi mencerminkan ukuran karya mereka diantara para karyawan itu sendiri, keluarga dan masyarakat. Kompensasi acapkali disebut penghargaan dan dapat didefinisikan sebagai setiap bentuk penghargaan yang diberikan kepada karyawan sebagai balas jasa atas kontribusi yang mereka berikan kepada organisasi

Menurut Milkovich dan Newman (2002), kompensasi total mencakup bayaran yang secara langsung diterima sebagai kompensasi kas (seperti: gaji dasar, insentif, biaya penyesuaian sehari-hari) dan yang tidak langsung sebagai benefit (seperti: dana pensiun, asuransi medis). Pemilik perusahaan menggunakan benefit untuk menarik dan 
mempertahankan orang-orang yang bekerja dengan baik, sedangkan pekerja sendiri mengadalkan benefit untuk mengamankan finasial mereka

Menurut Sondang P Siagian (2013) pada umumnya kompensasi diberikan untuk : (a) Menarik karyawan yang cakap masuk ke dalam organisasi, (b) Mendorong karyawan untuk berprestasi tinggi, (c) Mempertahankan karyawan yang produktif dan berkualitas agar tetap setia. Pelaksanaan kompensasi dapat berjalan efektif, dengan menerapkan azas kompensasi, yaitu :

a) Azas adil, besarnya kompensasi yang diberikan kepada karyawan harus disesuaikan dengan prestasi kerja, jenis pekerjaan, resiko pekerjaan, tanggung jawab, resiko pekerjaan, tanggung jawab, jabatan pekerjaan dan memenuhi persyaratan internal secara konsisten.

b) Azas layak dan wajar, kompensasi yang diberikan kepada karyawan harus dapat memenuhi kebutuhannya pada tingkat normatif yang ideal. Berdasarkan azas layak, penetapan besarnya kompensasi didasarkan atas batas upah minimum regional yang telah ditetapkan pemerintah. Prinsip adil dan layak harus mendapatkan perhatian khusus dengan tujuan balas jasa yang akan diberikan dapat merangsang gairah kerja dan pencapaian kepuasan kerja para karyawan.

Keadilan pemberian kompensasi ada dua macam yaitu keadilan internal dan keadilan eksternal. Keadilan internal merupakan perbandingan antara hasil yang diperoleh dengan usaha yang telah dilakukan untuk mencapai hasil tersebut. Keadilan internal mencakup apakah kompensasi yang diterima karyawan sudah sesuai dengan input yang diberikan oleh para karyawan yaitu pengalaman, kinerja atau produktivitas, masa kerja, waktu, tenaga, tingkat pendidikan dan keahlian khusus yang dimiliki karyawan.

Keadilan eksternal merupakan perbandingan hasil yang diperoleh seorang karyawan dengan hasil yang diperoleh seorang karyawan dengan hasil yang diperoleh karyawan lain yang memiliki kualifikasi dan tugas yang sama. Keadilan eksternal mencakup apakah kompensasi yang diterima oleh karyawan sama atau setidaknya sesuai dengan kompensasi yang diterima karyawan lain yang memiliki tugas dan pekerjaan yang sama dalam satu perusahaan.

Pendapat yang senada juga disampaikan Adam yang dikutip oleh Rivai dalam teori keadilan yang menyatakan bahwa setiap karyawan akan membandingkan rasio input dan outcomes dari comparison person. Apabila tercapai perimbangan antara input dan outcomes serta comparison person, maka outcomes bisa dikatakan adil.

Komitmen organisasi merupakan suatu pemahaman khusus dari individu sebagai ikatan psikologis pada organisasi termasuk rasa terlibat dengan pekerjaan, komitmen dan 
percaya akan nilai-nilai organisasi. Dalam hal ini komitmen yang dimaksudkan bukan sekedar setia semata akan tetapi lebih dari itu. Hal ini diperkuat Robbins, (2008) yang menyatakan bahwa komitmen organisasi adalah suatu bentuk keterdekatan yang bersifat psikologis antara anggota dengan organisasinya. Robbins (2008) mengemukakan pengertian komitmen adalah suatu keadaan dimana seorang karyawan memihak pada suatu organisasi tertentu dan tujuantujuannya, serta berniat memelihara keanggotaan dalam organisasi itu.

Sutarto Wijoyo (2010) mengemukakan perusahaan atau organisasi adalah suatu unit sosial atau sekelompok manusia yang bekerja sama untuk mencapai suatu tujuan, karena di dalam organisasi akan terjadi interaksi antar person, baik di antara bawahan dengan atasan atau sebaliknya

\section{Gaji}

Gaji adalah balas jasa dalam bentuk uang yang diterima oleh pegawai karyawan/ pegawai sebagai konsekuensi dari statusnya sebagai seorang karyawan atau pegawai yang memberikan kontribusi dalam mencapai tujuan organisasi/ perusahaan. karyawan yang diberikan gaji tetap, yaitu menerima pembayaran yang konsisten dari waktu ke waktu dengan tidak memperhatikan jumlah waktu jam kerja.

Dengan gaji tetap tersebut dalam pandangan umum akan memberikan status yang lebih tinggi dibandingkan dengan penerima upah harian. Beberapa organisasi telah mengganti menjadi pendekatan gaji tetap secara keseluruhan untuk karyawan tertentu dengan pertimbangan untuk menciptakan rasa loyalitas dan komitmen terhadap organisasi yang lebih besar. Namun organisasi tetap membayar kerja lembur untuk karyawan tertentu yang di tentukan oleh peraturan gaji yang ada. Dengan demikian gaji di sini merupakan bayaran yang konsisten dari satu periode ke periode lain dengan tidak memandang jumlah jam kerja.

\section{Tunjangan}

Simamora (2012) menyatakan bahwa tunjangan karyawan (employee benefit) adalah pembayaran-pembayaran (payment) dan jasa-jasa yang melengkapi gaji pokok, dan perusahaan membayar semua atau sebagian dari tunjangan itu. Tunjangan dapat di bagi kedalam tiga kategori. Pertama tunjangan-tunjangan yang menggantikan pendapatan (income) seperti tunjangan keamanan sosial dan pensiun menggantikan pendapatan pada waktu pensiun, kontinuitas gaji, dan program-program bagi yang tidak mampu, cacat yang jangka panjang dan jangka pendek menggantikan pendapatan karena sakit atau cacat kedua tunjangan-tunjangan yang memberikan rasa aman bagi kalangan karyawan dengan membayar pengeluaran-pengeluaran ekstra atau luar biasa yang di alami secara tidak terduga. Programprogram tunjangan yang dipandang sebagai kesempatankesempatan bagi karyawan 


\section{Insentif}

Insentif adalah pemberian tambahan upah untuk menghargai dan menambah motivasi karyawan berkait kerja atau kinerjanya yang berhasil. Tujuan utamanya adalah untuk memberikan tanggung jawab dan dorongan kepada karyawan guna meningkatkan kualitas dan kuantitas hasil kerjanya atau meningkatkan produktivitasnya. Sistem pemberian insentif bisa berdasarkan jumlah outfut yang dihasilkan pekerja; berdasarkan bonus produksi; komisi; pengalamannya bekerja, prestasi; kelangkaan profesi; prestasi kepempininan dalam membawa keuntungan perusahaan dan lain-lain.

\section{Bonus}

Bonus yaitu pembayaran tambahan di luar gaji atau upah sebagai hadiah atau perangsang. Diberikan sekali terima tanpa suatu ikatan dimasa mendatang. Bonus diberikan pada karyawan yang mampu bekerja sedemikian rupa sehingga tingkat produksi yang baku terlampaui.

\section{Asuransi}

Asuransi suatu instrumen sosial yang menggabungkan resiko individu menjadi resiko kelompok dan menggunakan dana yang dikumpulkan oleh kelompok tersebut untuk membayar kerugian yang diderita. Dalam asuransi kesehatan, resiko sakit secara bersamasama ditanggung oleh peserta dengan mengumpulkan premi ke perusahaan atau badan penyelenggara asuransi kemudian pihak asuransi mentransfer resiko individu ke suatu kelompok dan membagi bersama jumlah kerugian dengan proporsi yang adil oleh seluruh anggota kelompok (Ilyas, 2012).

\section{Jaminan pensiun}

Jaminan pensiun merupakan jaminan sosial yang bertujuan untuk mempertahankan kehidupan yang layak bagi karyawan, yang akan diberikan ketika karyawan memasuki masa pensiun. Premi jaminan pensiun ini akan dibayarkan oleh perusahaan.

\section{METODOLOGI}

Penelitian ini merupakan penelitian asosiatif kausal dengan pendekatan kuantitatif. Sampel diperoleh dengan menggunakan purposive sampling dengan kriteria perawat yang merupakan karyawan tetap dan telah bekerja dari 4 sampai 10 tahun diperoleh 81 sampel.

Variabel independen keadilan kompensasi diproksikan dalam gaji, insentif, bonus, tunjangan, asuransi dan jaminan pensiun. Kusioner yang disusun telah memenuhi kriteria validitas dimana semua item butir pertanyaan adalah valid, dan memenuhi kriteria reliabilitas dimana semua variabel diperoleh nilai cronbach alfa lebih besar dari 0,7 . 
Pengumpulan data menggunakan kuesioner dan wawancara. Tipe pertanyaan dalam kuesioner adalah pertanyaan tertutup dan terbuka dimana responden diminta untuk membuat pilihan diantara serangkaian alternatif yang diberikan. Skala data jawaban responden atas pertanyaan penelitian dengan menggunakan Agree-Disagree Scale yang menghasilkan jawaban sangat tidak setuju - jawaban sangat setuju dalam rentang nilai 1 sampai dengan 5 yang dikenal sebagai Skala Likert. Analisis data dilakukan menggunakan analisis regresi linear berganda.

\section{PEMBAHASAN}

Uji normalitas dilakukan dengan menggambarkan data masing-masing variabel menggunakan pp-plot. Gambar menunjukkan bahwa titik-titik menyebar di sekitar garis diagonal dan penyebarannya mengikuti arah garis diagonal. Dengan demikian dapat dinyatakanlah bahwa penyebaran data mendekat normal atau memenuhi asumsi normalitas.

Uji multikolinearitas digunakan untuk mengukur ada tidaknya hubungan linier antar variabel bebas. Kriteria ada tidaknya multikolinearitasan diukur menggunakan VIF. Apabila nilai VIF kurang dari 10, maka antar variabel bebas dinyatakan tidak terjadi multikolinearitas (Iman Ghozali, 2013). Hasil menunjukkan nilai VIF yang lebih kecil dari 10, maka dapat dinyatakan bahwa tidak terjadi multikolinearitas antar variabel bebas. Uji heterokedastisitas menggunakan uji Park dimana diperoleh hasil bahwa semua variabel memperoleh nilai signifikansi lebih besar dari 0,05 maka tidak terjadi heteroskedastisitas. Penelitian ini memenuhi kriteria uji asumsi klasik maka analisis regresi linear dapat dilanjutkan.

Analisis deskriptif bertujuan memberikan gambaran terhadap data-data pada variabel yang digunakan dalam penelitian yang menunjukkan gambaran masing-masing variabel yang dilihat dengan nilai minimum, maximum mean, dan standar deviasi yang dapat dilihat pada Tabel 1.

Tabel 1. Statistik deskriptif

\begin{tabular}{|c|c|c|c|c|c|c|c|c|}
\hline & & $\begin{array}{c}\text { KOMIT } \\
\text { MEN }\end{array}$ & GAJI & $\begin{array}{c}\text { INSENT } \\
\text { IF }\end{array}$ & $\begin{array}{c}\text { BONU } \\
\mathrm{S} \\
\end{array}$ & $\begin{array}{c}\text { TUNJAN } \\
\text { GAN }\end{array}$ & $\begin{array}{c}\text { ASURA } \\
\text { NSI }\end{array}$ & $\begin{array}{c}\text { JAMINANPEN } \\
\text { SIUN } \\
\end{array}$ \\
\hline \multirow[t]{2}{*}{$\mathrm{N}$} & Valid & 81 & 81 & 81 & 81 & 81 & 81 & 81 \\
\hline & Missin & 0 & 0 & 0 & 0 & 0 & 0 & 0 \\
\hline \multicolumn{2}{|c|}{ Mean } & 13,4815 & $\begin{array}{r}12,777 \\
8\end{array}$ & 13,3457 & $\begin{array}{r}12,938 \\
3\end{array}$ & 13,6296 & 6,3333 & 12,1235 \\
\hline \multirow{2}{*}{\multicolumn{2}{|c|}{$\begin{array}{l}\text { Std. } \\
\text { Deviation } \\
\text { Minimum }\end{array}$}} & 1,94365 & $\begin{array}{r}1,8973 \\
7\end{array}$ & 1,73321 & $\begin{array}{r}1,5680 \\
1\end{array}$ & 2,05210 & 1,81659 & 2,08796 \\
\hline & & 10,00 & 9,00 & 9,00 & 10,00 & 10,00 & 2,00 & 9,00 \\
\hline
\end{tabular}




\begin{tabular}{llllllll}
\hline Maximum & 16,00 & 16,00 & 16,00 & 16,00 & 17,00 & 10,00 & 16,00 \\
\hline
\end{tabular}

Komitmen mempunyai nilai minimum 10 dan maksimum 16, nilai rata-rata (mean) 13,48 dengan standar deviasi 1,94. Nilai standar deviasi yang lebih kecil dari mean menunjukkan bahwa tingkat penyimpangan datanya kecil sehingga menunjukkan data yang baik.

Gaji mempunyai nilai minimum 9 dan maksimum 16, nilai rata-rata (mean) 12,78 dengan standar deviasi 1,89. Nilai standar deviasi yang lebih kecil dari mean menunjukkan bahwa tingkat penyimpangan datanya kecil sehingga menunjukkan data yang baik.

Insentif mempunyai nilai minimum 9 dan maksimum 16, nilai rata-rata (mean) 13,35 dengan standar deviasi 1,73. Nilai standar deviasi yang lebih kecil dari mean menunjukkan bahwa tingkat penyimpangan datanya kecil sehingga menunjukkan data yang baik.

Bonus mempunyai nilai minimum 10 dan maksimum 16, nilai rata-rata (mean) 12,94 dengan standar deviasi 1,57. Nilai standar deviasi yang lebih kecil dari mean menunjukkan bahwa tingkat penyimpangan datanya kecil sehingga menunjukkan data yang baik.

Tunjangan mempunyai nilai minimum 10 dan maksimum 17, nilai rata-rata (mean) 1,62 dengan standar deviasi 2,05. Nilai standar deviasi yang lebih kecil dari mean menunjukkan bahwa tingkat penyimpangan datanya kecil sehingga menunjukkan data yang baik

Asuransi mempunyai nilai minimum 2 dan maksimum 10, nilai rata-rata (mean) 6,33 dengan standar deviasi 1,83. Nilai standar deviasi yang lebih kecil dari mean menunjukkan bahwa tingkat penyimpangan datanya kecil sehingga menunjukkan data yang baik

Jaminan Pensiun mempunyai nilai minimum 9 dan maksimum 16, nilai rata-rata (mean) 12,12 dengan standar deviasi 2,09. Nilai standar deviasi yang lebih kecil dari mean menunjukkan bahwa tingkat penyimpangan datanya kecil sehingga menunjukkan data yang baik.

Tabel 2. koefisien determinasi

\begin{tabular}{lrrrr}
\hline Model & R & R Square & $\begin{array}{c}\text { Adjusted R } \\
\text { Square }\end{array}$ & $\begin{array}{l}\text { Std. Error of } \\
\text { the Estimate }\end{array}$ \\
\hline 1 &, $946^{\mathrm{a}}$ &, 894 &, 886 &, 65647 \\
\hline
\end{tabular}

a. Predictors: (Constant), JAMINANPENSIUN, ASURANSI, GAJI, BONUS, TUNJANGAN, INSENTIF

Sumber : Data diolah (2018)

Koefisien determinasi digunakan untuk mengetahui seberapa besar variabel gaji, insentif, bonus, tunjangan, asuransi dan jaminan pensiun mampu menjelaskan terhadap 
komitmen organisasi. Nilai koefisien determinasi sebesar 0,886 hal ini menunjukan bahwa variasi komitmen organisasi mampu dijelaskan oleh gaji, insentif, bonus, tunjangan, asuransi dan jaminan pensiun sebesar $88,6 \%$ dan sisanya $11,4 \%$ oleh variabel lain di luar model.

Tabel 3. Uji F

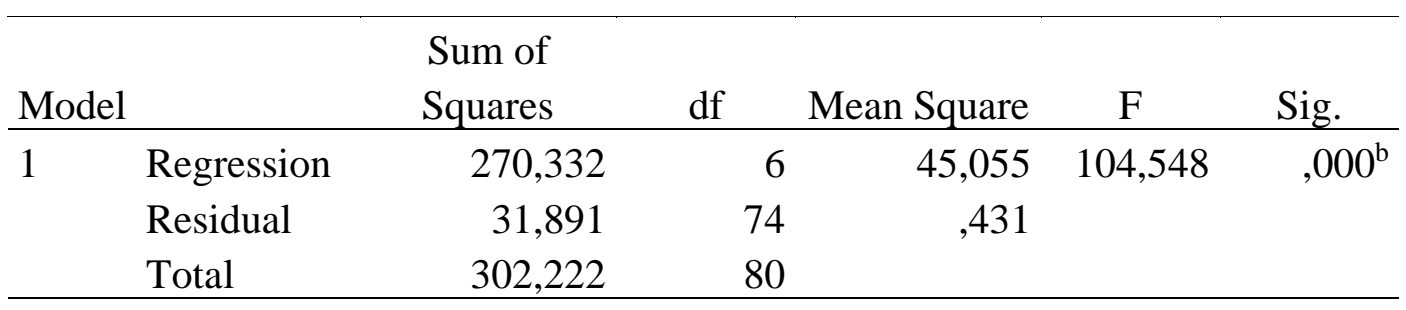

Sumber : Data diolah (2018)

Hasil menunjukkan bahwa nilai $\mathrm{F}$ hitung sebesar 104,548 dengan signifikansi 0,00 , dimana nilai ini lebih kecil dari $\alpha=5 \%$ hal ini menunjukkan bahwa model regresi dapat digunakan untuk memprediksi komitmen organisasi.

Tabel 4. Uji t

\begin{tabular}{|c|c|c|c|c|c|c|}
\hline \multirow[b]{2}{*}{ Model } & & \multicolumn{2}{|c|}{$\begin{array}{l}\text { Unstandardized } \\
\text { Coefficients }\end{array}$} & \multirow{2}{*}{$\begin{array}{c}\text { Standardized } \\
\text { Coefficients } \\
\text { Beta } \\
\end{array}$} & \multirow[b]{2}{*}{$\mathrm{t}$} & \multirow[b]{2}{*}{ Sig. } \\
\hline & & $\mathrm{B}$ & Std. Error & & & \\
\hline 1 & (Constant) &,- 896 &, 700 & & $-1,280$ & ,205 \\
\hline & GAJI & ,039 & ,049 &, 038 & ,799 & ,427 \\
\hline & INSENTIF & , 169 & ,074 &, 151 & 2,277 & ,026 \\
\hline & BONUS & , 138 & ,065 & ,112 & 2,124 & ,037 \\
\hline & TUNJANGAN & ,609 & ,060 & ,643 & 10,085 &, 000 \\
\hline & ASURANSI & ,044 & ,043 &, 042 & 1,024 & ,309 \\
\hline & $\begin{array}{l}\text { JAMINANPENSI } \\
\text { UN }\end{array}$ & , 103 & ,046 &, 111 & 2,231 & ,029 \\
\hline
\end{tabular}

Persamaan regresi linear berganda dapat disusun sebagai sebagai berikut:

Komitmen $=-0,896+0,39$ Gaji + 0,169 Insentif $+0,138$ Bonus $+0,609$ Tunjangan $+0,44$ Asuransi + 0,103 Jaminan Pensiun

Persamaan regresi di atas menunjukkan bahwa koefisien regresi variabel komitmen organiasi adalah -0,896 nilai koefisien yang negatif menunjukkan bahwa jika tanpa ada keadilan kompensasi maka karyawan tidak akan memiliki komitmen organisasi. Semua variabel independen memiliki koefisien regresi positif artinya semakin tinggi karyawan merasakan keadilan kompensasi maka komitmen terhadap organisasi akan semakin tinggi. 
Dari hasil penelitian diperoleh nilai t untuk variabel gaji sebesar 0,779 dengan nilai signifikansi sebesar 0,427 , dimana nilai ini tidak signifikan pada tingkat signifikan $\alpha=5 \%$ karena lebih besar dari 0,05, dengan demikian hipotesis pertama diterima maka gaji tidak berpengaruh signifikan terhadap komitmen organisasi. Hal ini terjadi karena merasakan bahwa gaji yang mereka terima masih belum sepadan dengan beban kerja yang harus dilakukan dan mereka mengetahui bahwa ada rumah sakit swasta lain yang bisa memberikan gaji yang lebih tinggi. Dari hasil penelitian diperoleh bahwa hanya $43 \%$ yang menyatakan gaji yang diterima sudah sesuai dengan yang disepakati dalam perjanjian kerjasama sudah sesuai harapan responden.

Hasil yang diperoleh bertentangan dengan penelitian dari Wilujeng Rahayu (2012) yang menyatakan bahwa semakin positif persepsi karyawan terhadap keadilan kompensasi maka akan semakin komitmen organisasinya. Hal ini sejalan dengan penelitian Dewi Puspitasari, (2011) yang menyatakan bahwa pendapatan finansial bukan merupakan motivasi utama karyawan dalam bekerja, dimana karyawan mempunyai keinginan mengabdi dan niat beribadah.

Nilai t untuk variabel insentif sebesar 2,278 dengan nilai signifikansi sebesar 0,26, dimana nilai ini signifikan pada tingkat signifikan $\alpha=5 \%$ karena lebih kecil dari 0,05 , dengan demikian hipotesis kedua ditolak,maka insentif berpengaruh positif signifikan terhadap komitmen organisasi. Hasil yang sejalan dengan penelitian dari Wilujeng Rahayu, (2012), Adie Hasthina, (2017).

Nilai t untuk variabel bonus sebesar 2,12 dengan nilai signifikansi sebesar 0,37, dimana nilai ini signifikan pada tingkat signifikan $\alpha=5 \%$ karena lebih kecil dari 0,05 , dengan demikian hipotesis ketiga ditolak,maka bonus berpengaruh positif signifikan terhadap komitmen organisasi.

Nilai t untuk variabel tunjangan sebesar 10,09 dengan nilai signifikansi sebesar 0,00, dimana nilai ini signifikan pada tingkat signifikan $\alpha=5 \%$ karena lebih kecil dari 0,05 , dengan demikian hipotesis keempat ditolak,maka tunjangan berpengaruh positif signifikan terhadap komitmen organisasi.

Nilai t untuk variabel asuransi sebesar 1,02 dengan nilai signifikansi sebesar 0,31 dimana nilai ini signifikan pada tingkat signifikan $\alpha=5 \%$ karena lebih besar dari 0,05 , dengan demikian hipotesis kelima diterima, maka asuransi tidak berpengaruh signifikan terhadap komitmen organisasi. Hal ini terjadi karena sebelum ikut asuransi BBJS ketika sakit karyawan mendapatkan fasilitas pengobatan dari rumah sakit tersebut. Adanya asuransi mengharuskan karyawan berobat di fasilitas kesehatan terdekat dari tempat tinggalnya, sehingga karyawan 
merasa dirugikan karena tidak memperoleh pengobatan dari tempatnya bekerja yang dirasakan lebih bagus dan nyaman.

Nilai t untuk variabel jaminan pensiun sebesar 2,23 dengan nilai signifikansi sebesar 0,029, dimana nilai ini signifikan pada tingkat signifikan $\alpha=5 \%$ karena lebih kecil dari 0,05 , dengan demikian hipotesis keenam ditolak,maka jaminan pensiun berpengaruh positif signifikan terhadap komitmen organisasi.

\section{KESIMPULAN}

Dari hasil penelitian diperoleh kesimpulan bahwa : gaji tidak berpengaruh signifikan terhadap komiten organisasi, bonus berpengaruh positif signifikan terhadap komitmen organisasi , insentif berpengaruh positif signifikan terhadap komitmen organisasi, tunjangan berpengaruh positif signifikan terhadap komitmen organisasi, Asuransi tidak berpengaruh signifikan terhadap komitmen organisasi, Jaminan Pensiun berpengaruh positif signifikan terhadap komitmen organisasi.

Penelitian selanjutnya agar memasukan variabel lain yang mengaruhi komitmen organisasi misal kepuasan kerja, peran pemimpin dan lainnya.

\section{DAFTAR PUSTAKA}

Adie Hasthina, 2017. Hubungan antara keadilan kompensasi dan komitmen organisasi dengan produktivitas kerja pada karyawan PT. X di samarinda 1, psikoborneo, 2017, 5: 654667), http : ejournal.psikologi.fisip-unmul.ac.id.

Andrew E. Sikula. 2011. Manajemen Sumber Daya Manusia, Erlangga. Bandung

Ervanda Wildam et.al ( 2016), Pengaruh Kompensasi Dan Kepusan Kerja Terhadap Komitmen Organisasional (Studi pada Karyawan KSP Sumber Dana Mandiri Gresik) $\begin{array}{llllllll}\text { Jurnal Administrasi Bisnis (JAB) } & \text { Vol. } 34 & \text { No. } & 1 & \text { Mei } & 2016\end{array}$ http:administrasibisnis.studentjournal.ub.ac.id.

Dewi Puspitasari dan Setia Arsyanti 2011. Faktor Yang Paling Berpengaruh Terhadap Komitmen Kerja Perawat Panti Wreda Di Surakarta, Jurnal Psikologi Undip Vol. 9, No.1, April 2011.

Danang Sunyoto, 2015. Penelitian Sumber Daya Manusia: Teori, Kuesioner, Alat Analisis dan Contoh Riset, CAPS Yogyakarta.

Ilyas, Yaslis. 2012. Kinerja, teori, penilaian dan penelitian. Jakarta: Pusat Kajian Ekonomi Kesehatan FKM Universitas Indonesia.

Imam Ghozali, 2013. Aplikasi Analisis Multivariate Dengan Program SPSS, Edisi Ketiga, Badan Penerbit Universitas Diponegoro, Semarang. 
Kadek Ratih Dwi Oktarini dan Komang Rahayu Indrawati, 2014. Hubungan Antara Persepsi Terhadap Keadilan Kompensasi dengan Komitmen Organisasi di Hospitality Industry, Jurnal Psikologi Udayana 2014, Vol. 1, No. 2, 291-300. https://ojs.unud.ac.id/index.php/psikologi/article/view/.../16302

Milkovich, G. dan Newman. (2002). Compensation. 7 th edition. America : Mc Graw - Hill Irwin

Robbins, S.P dan Timothy A.J. (2008). Organizational Behaviour (12 ed.). Jakarta: Salemba Empat.

Henry Simamora, 2012. Manajemen Sumber Daya Manusia. Edisi 1. Yogyakarta: STIE YKPN Yogyakarta.

Sondang P. Siagian, 2013, “ Manajemen Sumber Daya Manusia”, , Jakarta: Bumi Aksara

Sugiyono. 2008. Metode Penelitian Kunatitatif Kualitatif dan R\&D. Alfabeta.Bandung

Sudarwanti Retnaningsih, 2007. Analisis Pengaruh Keadilan Kompensasi, Peran Kepemimpinan, Dan Kepuasan Kerja Terhadap Komitmen Organisasi Dalam Meningkatkan Kinerja Karyawan (Studi Kasus: Pada Sentral Pengolahan Pos Semarang), http://eprints.undip.ac.id/35513/1/SDM.13D-Sudarwati_Retnaningsih2007.pdf

Sutarto Wijono. (2010). Psikologi Industri dan Organisasi. Jakarta: Fajar Interpratama Offset.

Werther William B. and Davis Keith,(1996), Human Resources and Personal Management. New York: Mc.GrawHill

Wilujeng Rahayu, (2012). Persepsi Keadilan Kompensasi Terhadap Komitmen Organisasional Melalui Kepuasan Kerja, Jurnal Manajemen Bisnis, Volume 2 No. 01 Edisi April 2012, https://media.neliti.com/media/publications/110657-ID-persepsikeadilan-kompensasi-terhadap-ko.pdf 